\title{
The Art of Begging
}

\author{
Adriana Margareta Dancus
}

Begging migrants from Romania have been a familiar sight in major European cities ever since Romania joined the European Union (EU) in 2007. Following the economic crisis in the EU, these migrants have become increasingly visible in Norway and Sweden as well, where affluence, combined with a legal acceptance of begging, has made both countries attractive destinations for this group of people (Djuve et al. 2015; Olsson 2015). As the numbers of begging migrants continue to rise, the public and policy debates about begging in Scandinavia become more heated and polarized. Right-wing political parties in both Norway and Sweden have lobbied for a national ban on begging, while non-profit organizations such as Kirkens Bymisjon (The Church City Mission), which perform outreach work on the streets of Norwegian towns and cities, have repeatedly called for acceptance and care for this group of migrants. The bone of contention in public and policy debates in Scandinavia has been whether or not ringleaders and traffickers control the begging migrants (Djuve et al. 2015; NRK 2017).

\footnotetext{
A. M. Dancus $(\bowtie)$

Department of Languages and Literature Studies, University of South-Eastern Norway, Bakkenteigen/Borre, Norway

e-mail: Adriana.M.Dancus@usn.no
}

(C) The Author(s) 2020

A. M. Dancus et al. (eds.),

Vulnerability in Scandinavian Art and Culture, https://doi.org/10.1007/978-3-030-37382-5_11 
Such debates demonstrate that the figure of the begging migrant is a highly affective trope, mobilizing an entire spectrum of emotional responses from empathy and a willingness to help, to consternation and fear. But what happens when contemporary Scandinavian artists involve begging migrants from Romania in their art? How do Scandinavian artists initiate collaborations with real begging migrants in the 2010s? In this chapter, I discuss these questions by looking more closely at two projects: Toleranshuvan Reloaded. "A pair of rubber gloves called tolerance" (2015, from now on referred to as Toleranshuvan Reloaded) and the multiplatform project Det kunde varit jag (It Could Have Been Me) (2012-2015). The first is a performance at the Malmö Fine Arts Museum for which the Swedish theatre group Institutet paid two begging migrants from Romania to pose as beggars ${ }^{1}$ in one of the museum's white rooms. The performance was part of a larger exhibition at the Malmö Fine Arts Museum entitled The Alien Within-A Living Laboratory of Western Society, which brought together a think tank around the political work of German theatre director, filmmaker and visual artist Christoph Schlingensief (Malmö Konsthall 2015). It Could Have Been Me is a project led by the Swedish cartoonist Sara Olausson in collaboration with Felicia Iosif, a woman from Romania begging in a Stockholm suburb. It combines graphic short stories drawn by Olausson with various forms of community action, including fundraising on social media. There are other collaborations between Scandinavian artists and begging migrants from Romania that could have been included in this chapter, such as Presserom (2014) by the Norwegian artist Morten Traavik and How Do You Become a Successful Beggar in Sweden? (2015) by the Swedish artist Cecilia Parsberg. Given the scope of this chapter, I have chosen to limit my discussion to Toleranshuvan Reloaded and It Could Have Been Me because both projects have generated significant public debates and left affective traces that I could track through a review of the media and a book issued in connection with It Could Have Been Me. ${ }^{2}$ I frame my approach to these two projects through the notion of vulnerability as tactical.

In the introduction to the book Vulnerability in Resistance, the editors point out how 'the concept of vulnerability always operates in a tactical field': groups in positions of power commonly deny and disavow their own vulnerability and, instead, project it onto those whom they seek to contain or exclude; on other occasions, the very same groups may deploy the language of vulnerability about themselves as a way to protect their own privilege (Butler et al. 2016, pp. 4-5). In a separate chapter 
in Vulnerability in Resistance, American philosopher and gender scholar Judith Butler (2016) comes back to the notion of vulnerability as tactical, and distinguishes between forms of corporeal and linguistic vulnerability. Her theoretical observations are grounded in non-violent street protests in which protesters deliberately expose their vulnerable bodies to power (police, security, military) in a call for justice and equality. Further, Butler couples this form of corporeal vulnerability to a linguistic vulnerability, in so far 'who we are, even our ability to survive depends on the language that sustains us' $(2016$, p. 16). She then explains that vulnerability is a 'way of being exposed and agentic at the same time' (2016, p. 24), 'neither fully passive, nor fully active, but operating in a middle region' (2016, p. 25), and concludes that vulnerability can be 'marshaled and mobilized for the purposes of resistance' (2016, p. 26). In other words, vulnerability, as Butler defines it, plays an important role in resistance and should not be understood in opposition to it.

How can Toleranshuvan Reloaded and It Could Have Been Me be understood through the lens of vulnerability as tactical, and how does this theoretical approach lend itself to a critical reading of the use of real people in art? I will begin this chapter with a discussion of begging and vulnerability.

\section{Begging AND VULNERABILITY}

On 16 May 2014, Sweden's Radio Channel 1 invited Sara Olausson, the artist behind the multiplatform project It Could Have Been Me, to debate in a morning news programme against Björn Söder, a profiled name in the far-Right, nationalist party Sweden Democrats (Pl-morgon 2014). The topic of discussion was an anti-begging poster campaign launched by the Sweden Democrats in metro stations around Stockholm, a campaign many travellers regarded as 'racist and deceiving propaganda' (Asplund 2014). Söder was given the opportunity to speak first. He began by claiming that criminal networks controlled the migrants who begged in Sweden. He then argued for a ban on begging as the only effective measure to address the problem:

The most important thing is to look at those who are exploited. Should we allow that they continue to be exploited? And second, should we take care of all the citizens in Europe? All the countries that are part of the EU have 
pledged to take care of their citizens. Romania is responsible. (Pl-morgon 2014 , my translation)

Although Söder does not use the word 'vulnerability', he implies that begging presupposes vulnerability in at least two senses: the vulnerability of the begging migrants, who are exploited by criminal networks; and the vulnerability of the Swedes, who have no responsibility to take care of foreign citizens from other EU countries.

In contrast to Söder, who uses various reports and statements to back up his party's anti-begging campaign, Olausson underlines her own experiences of making the acquaintance of begging migrants on the streets of Stockholm and that witness a very different picture: 'They are very poor and vulnerable people, who have come here to survive, and I have not come across organized begging. None of us who work closely with these people have' (my translation and emphasis). Olausson sees the begging migrants' vulnerability as a result of the poverty and the discrimination these people face in Romania, where they are unable to find jobs. She also underlines that Swedes should help people in need, irrespective of their national affiliation: 'I also want to stop begging. As I said, it does not do anyone any good. But we must have an alternative, otherwise these people are left to die' (Pl-morgon 2014, my translation).

The debate between Söder and Olausson is illustrative of how both those in favour and those against a ban on begging use vulnerability as an important argument in public debates in Scandinavia. ${ }^{3}$ In an attempt to bring clarity to such debates, a team of researchers from the Norwegian research foundation Fafo conducted fieldwork and interviewed several hundreds of Norwegian outreach workers and homeless Romanian citizens (both ethnically Roma and non-Roma) who begged, collected plastic bottles and sold small items on the streets of Oslo, Stockholm and Copenhagen (Djuve et al. 2015). The Fafo-researchers addressed the question of vulnerability as a separate point in their investigation. They concluded that the homeless street workers from Romania were, indeed, vulnerable, but not to trafficking, as claimed by many politicians in Norway and Sweden (Djuve et al. 2015, p. 80). Instead, vulnerability in this group took many other forms: the vulnerability to being exploited for casual work, and unrealistic expectations regarding the rewards from begging; the vulnerability to falling prey to petty crime and abuse in an attempt to survive on the streets of Scandinavian capitals; the vulnerability to alcohol and drug abuse, and to the risk of being entangled in the local 
drug scenes; and the vulnerability to the risk of not being able to earn enough through begging and pay back their debts to the minibus drivers that facilitated their travel to Scandinavia (Djuve et al. 2015, pp. 84-85).

The Fafo-report analysed vulnerability exclusively as a condition inscribed in the bodies of the begging migrants. In Norway, in the late spring of 2017, vulnerability was, however, attributed to the inhabitants of Oslo, whose recreational areas and kindergarten yards the begging migrants from Eastern Europe transformed into what was referred to as 'Roma camps' filled with garbage and human excrement (Kirkerud and Baraldsnes 2017). The municipal authorities in Oslo were summoned to find effective solutions to prevent the spreading of disease among the inhabitants of Oslo. Kindergarten children living in the exposed areas were of particular concern, as kindergarten personnel found several of them playing in areas where excrement had been passed outdoors by the migrants (Kirkerud and Baraldsnes 2017). If Söder was concerned with the economic toll put on Sweden by foreign citizens, in 2017 in Norway, it was the public health argument that made the headlines, this time advanced on behalf of kindergarten children whose vulnerability was exacerbated by begging migrants who took over their playgrounds. In this way, the migrants' vulnerability was framed in competition with that of Norwegian children.

These examples taken from Sweden and Norway show how vulnerability is used in a tactical field when begging migrants become the subject of debate. Vulnerability is an argument embraced both by those who are against and those who are for a ban on begging. Vulnerability is not merely a condition of the begging migrants, but also a description Norwegians and Swedes use about themselves in their interactions with the begging migrants. Additionally, vulnerability is a contested phenomenon that some voices tie, first and foremost, to organized crime and trafficking. Others see vulnerability primarily as a question of poverty, discrimination and unrealistic expectations. Scandinavian artists such Olausson and the theatre group Institutet participate in this tactical field when they choose to involve real begging migrants in their projects. The fact that Toleranshuvan Reloaded and It Could Have Been Me are simultaneously social interventions and artistic gestures dependent on the participation of real people makes it quite challenging to discuss these projects. The British art historian and critic Claire Bishop has been at the forefront of theoretical debates about the use of real people in art. I therefore wish to make a 
brief theoretical detour to Bishop, before turning to a discussion of the two Swedish projects.

\section{The Use of Real People in Art}

Bishop (2006) shows that, since the 1960s, many artists have used real people in their art, particularly with the advent of what has been described as the 'socially engaged', 'participatory', or 'relational' art of the 1990s. By 'real people', Bishop means 'participants from outside an artistic context who are chosen by the artist to represent a particular socio-economic demographic, ethnicity or gender' $(2006$, p. 62). Rather than using their own bodies to stage a performance for the public, high-profiled artists such as the Spanish artist Santiago Sierra delegate their performance to real people with a socioeconomic, racial and ethnical background that is quite different from that of the audience. Elsewhere, Bishop (2004) calls artistic gestures such as Sierra's 'antagonistic relational art'; that is, art that disrupts and provokes discomfort and frustration, rather than cultivates a convivial, positive relationship between the artist and the audience.

Shannon Jackson (2011), American rhetoric and theatre scholar, discusses how Bishop's penchant for antagonism in art instituted a problematic distinction between those artists who underlined the importance of community and conviviality, and those who cultivated tension and discomfort. Whereas Bishop (2006) criticized the first group for neutralizing the viewer's capacity to think critically and for trading off aesthetical for ethical concerns, she praised the latter for providing edgy art material with an aesthetic impact that shook the viewer into critical reflection. Jackson (2011), instead, argues that '[R]adically antagonistic art does not need to exist either in an extra-aesthetic space of community action or in an aesthetically protected space of ambiguous discomfort' (p. 60, emphasis in original).

The two Swedish projects to which I now wish to turn attention demonstrate how Bishop's critical intervention on behalf of antagonistic art is particularly deceiving when we shift our focus away from antagonism and towards vulnerability as tactical. The theatre group Institutet delegates their performances to begging migrants from Romania against remuneration when casting real migrants as beggars inside an art gallery. Olausson, on the other hand, is an activist artist who decides to put herself on display together with Felicia Iosif. She sits down next to Iosif while the latter is begging. She also shares her own vulnerabilities as a mother, 
wife and artist in her graphic art and through her public participation in rallies and on social media. As we will see, this shared performance turns out to be quite costly for Olausson, provoking angry responses from some members of the audience. Neither Toleranshuvan Reloaded nor It Could Have Been Me can be easily placed on the antagonistic-convivial dyad instituted by Bishop, especially not when vulnerability becomes the centre of the investigation. Let us look more closely at each of the projects through the lens of vulnerability as tactical.

\section{Delegating Performance In Toleranshuvan ReLOADED}

Toleranshuvan Reloaded was artistically led by Anders Carlsson from the theatre group Institutet and builds on an earlier performance by the same group from 2010, entitled Toleranshuvan ('The Tolerance Hood'). For Toleranshuvan, the artists designed a collection of Ku Klux Klan inspired hoods to express tolerant values. Sent to party leaders and used at various public events, these tolerance hoods were meant to illustrate how tolerance could become a mechanism to avoid contact with the other, a way for the tolerant to hide behind their tolerant values. In 2015, Institutet returned to the ideas developed in Toleranshuvan but, instead of using hoods, they used the white art space as a place to question the Swedish public's tolerance with regard to begging migrants on the streets of Malmö. In an email to the author, Carlsson describes Toleranshuvan Reloaded as a multifaceted project with 'many behind-the-scenes stories that are highly relevant for a deeper understanding' of it (Carlsson 2017a). ${ }^{4}$ These stories make evident how both artists and begging migrants involved in Toleranshuvan Reloaded use vulnerability in a tactical field and, therefore, why this project is not simply antagonistic art as defined by Bishop. In what follows, I wish to reconstruct these stories and then flesh out the vulnerabilities at stake.

Carlsson and his team created what the Swedish press occasionally called a 'social installation', which the artists themselves described as 'an exhibition focusing [on] what happens inside of us, when-in an artspace-we meet the ones we are used to meet (but not really meet) in the street' (Institutet 2015). To be precise, two begging migrants from Romania, a couple, Marcela Chereși and Ioan Luca Lăcătuș, were paid to sit in begging postures in one of the smaller exhibit rooms at the Malmö's Fine Arts Museum for two hours, four days a week, for two weeks. 'We 
wanted to create a laboratory situation in which one can explore one's own image as a donor', says Carlsson in an interview (Stenbäck 2015). ${ }^{5}$

With the help of the Romanian activist and DJ Cătălin-Mihai Marghit, who was also paid by the project, Institutet recruited Chereși and Lăcătuş on the streets of Malmö, where they were begging, and invited them to act as beggars inside the Malmö Fine Arts Museum. Marghit also functioned as interpreter but, as Carlsson (2017b) explains, Institutet also used sign language to communicate with the two as well as some Italian words. Chereși and Lăcătuș received remuneration for their participation in the project, which they then taxed in Sweden: 140 Swedish kronor per hour, an honorarium recommended by the Swedish Union for Performing Arts and Film for people with an expert competence (Carlsson 2017b).

The two were chosen because they had a retable story to tell as well as 'an attitude and a look suitable for a sympathetic identification in the media' (Carlsson 2017b). The story told by Chereși and Lăcătuș was that their house burned to the ground on New Year's Eve in 2012, which then led to Lăcătuş losing custody of his two children from a previous relationship. The couple, now expecting their first child together, left Romania to beg in Western Europe in the hope of gathering enough money to rebuild their house and reunite their family.

As to their look and appearance, they were both in their late twenties, with white complexions, dark hair and brown eyes. Lăcătuș had an oval face framed by a beard, with slightly elongated eyes and a long, aquiline nose, while Chereși had a round face with full lips, thinly plucked eyebrows and long hair tied in a ponytail or covered with a Palestinian headscarf, also tied behind. For the performance, they wore warm, casual clothes, such as jumpers, pants and winter boots, and used props such as stools, a crutch and a homemade cardboard sign reading in capital letters in Swedish: 'I have two children and they have no house to live in. I need your help. Thank you' (my translation).

To enter the room, the visitors walked through a dark corridor adorned with five dark screens displaying the following text in Swedish: 'Today you do not have to give.' In the art room, Chereși and Lăcătuş sat in silence across from each other, at times on their stools, at other times directly on the wooden floor (see Fig. 11.1)

In the middle of the room, there was a bench on which visitors could rest. A large image of Institutet's logo was displayed on one of the walls; on another, collages and diagrams by the artist Linnea Carlsson outlining 


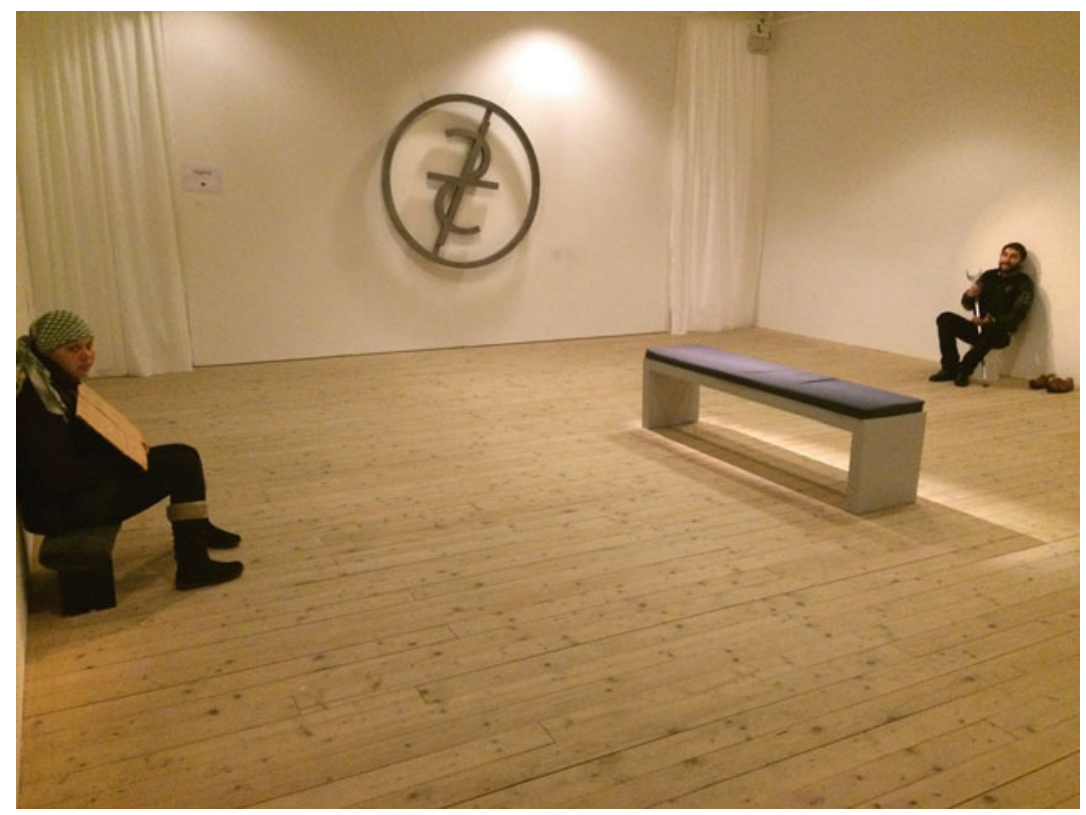

Fig. 11.1 Marcela Chereși and Ioan Luca Lăcătuş on display as beggars inside Malmö’s Fine Arts Museum (ㄷ Anders Carlsson at Institutet)

possible ways to protect the rights of the poor, such as the use of satire and social media, revolt and even guerilla warfare (Millroth 2015). As the artistic leader of Toleranshuvan Reloaded explains, one of the ideas sketched in the collages was the organization of a camp in which the poor would receive military training to attack those institutions that allowed the proliferation of injustice in our Western societies (Carlsson 2017b).

The visitors were not allowed to give money to the beggars. Neither were the beggars able to enter into a dialogue with the visitors, as no translator was present in the room. The dialogue was reduced to eye contact and small facial gestures. In the Swedish press, the visitors speak of meeting the two beggars with silence, humility, confusion, discomfort, a feeling of disempowerment and embarrassment. One woman chose to sit down next to Lăcătus,, rather than looking down on him; other visitors fled the embarrassment of the situation turning their gaze on Linnea Carlsson's collages (Stenbäck 2015). The scenarios of action outlined in 
the sketches were, however, not reassuring. Indeed, the thought of the poor organizing themselves in an army capable of performing acts of terror must have been unnerving, particularly when two potential 'soldiers' in that army sat at the visitors' feet and watched their movements in the exhibit room.

Eating their lunch in the museum's popular restaurant Smak, other museum guests explained why they chose not to see the performance: 'It is a pity that people are forced to beg and that artists then exploit their situation, I am not interested in that', one woman declared to the Swedish press (Ankersen 2015, my translation). Chereși and Lăcătuș were, on one occasion, asked to explain how it was for them to be displayed as beggars in an art gallery. 'People feel sorrier for us here than on the street', says Cheressi, while her boyfriend adds, 'It feels easier, it is warmer in here and there is a different atmosphere than out there' (Stenbäck 2015).

While some welcomed Institutet's willingness to test the visitor's tolerance by displaying begging migrants from Romania as beggars (Millroth 2015; Jönsson 2015), others deplored the project's insistence on focusing on the white and privileged Swedish public (Ekman 2015; Israelson 2015; Rooth 2015). Aaron Israelsson (2015), who at the time of the performance worked as editor-in-chief of the Swedish street magazine Faktum, called for art that brought to the fore the suffering of the poor, while journalist, writer and activist Kajsa Ekis Ekman (2015) suggested that Institutet put managers and directors on display, instead of beggars. The Swedish art historian, critic and author Thomas Millroth was, in principle, positively inclined to the idea of Toleranshuvan Reloaded because the performance blocked compassion and denied the visitor a better self-image. Yet, Millroth had an objection: 'Why should they [Chereși and Lăcătuş] be restricted to the art room of Institutet, why aren't they allowed to beg openly in Restaurang Smak or in the ongoing exhibition in the great hall?' (Millroth 2015, my translation).

Several representatives of the Roma communities in Sweden and Europe reacted negatively to the way in which Institutet showcased Chereși and Lăcătuș as Roma. Soraya Post, Swedish politician and member of the European Parliament, called the performance a 'freak show' in which the poor Roma were reduced to silent objects for the visitors to contemplate (Berglund 2015). Five days after the exhibit closed, Georghe Răducanu from the European Roma and Travellers Forum in Strasbourg sent an official letter of complaint to the director of Malmö's Fine Arts Museum. In the letter, Răducanu (2015) deplored the ways in which 
Toleranshuvan Reloaded reinforced stereotypes and prejudices about the Roma communities by casting Lăcătuş and Chereși in the predictable role of beggars. According to him, this artistic gesture impinged on the dignity of the Roma communities. He ended his letter with the following encouragement:

You would do so much more for tolerance by showcasing sides of Roma communities unknown to the general public, instead of capitalizing on a particularly difficult situation in which many members of the Roma communities find themselves. (Răducanu 2015)

In the aftermath of the performance, Institutet launched a fundraising campaign to gather 100,000 kronor for Lăcătuş and Chereși; however, the campaign was brought to a halt shortly after, before the two had received any money. Institutet had reasons to believe that Lăcătuş and Chereși lied about their story and provided other misleading information (Carlsson 2017b). After a Swedish citizen contacted Institutet with allegations of serious fraud against Lăcătuş and Chereși, Carlsson and his team decided to stop the fundraising and denied any form of contact with either of them, including contact on social media. In an email correspondence with the author, Carlsson adds:

To me, the story [that of Lăcătuş and Chereși] is unprecedented and deceiving. It amuses me that we, the artists, together with the press, were fooled in the end. I do not put any moral blame on them [Lăcătuş and Chereși] for having taken advantage of the situation and lied about their background. They told and showed what could give them an income. I think it is quite understandable. But it was very bad what they did to that man, which is why I do not have any form of contact with them. (Carlsson 2017b)

When reconstructing the various phases of Toleranshuvan Reloaded (preproduction, exhibition, reception, follow-up), it becomes clear that the Malmö exhibit draws on and sustains various forms of vulnerability that begging migrants, artists and the audiences share in unexpected ways. In the exhibit room, Lăcătuş and Chereși deliberately expose their bodies, yet they are not really able to speak out as Butler's street protesters do. The lack of common language skills and the absence of an interpreter makes it very difficult for visitors and beggars to interact with each other. Coupled with the fact that the visitors are not allowed to give money, this 
linguistic vulnerability, which visitors and beggars share, enhances the visibility of the beggars' corporeal vulnerability. In the white art space, visitors 'feel sorrier' for the two beggars, although the infrastructure provided by the Museum bears no comparison to what the begging migrants face on the open streets of Malmö in winter.

If some members of the Roma communities regarded Toleranshuvan Reloaded as a deplorable artistic gesture that reduced the two migrants to passive objects, the way the fundraising campaign ended suggests that Lăcătus and Chereși were neither fully passive, nor completely exposed, but, rather, partly active and even creative. According to Carlsson, the two marshalled and mobilized vulnerability in the media and in the art space in order to maximize their income. It is unclear to what extent the allegations of fraud brought against Lăcătuş and Chereși were well-founded. This chapter is not interested in settling that argument. On the other hand, it is worthy of note how Carlsson invokes the trope of fraud in order to explain the artistic gesture behind Toleranshuvan Reloaded. Historically speaking, fraud and imposture have been important arguments in anti-begging legislation and proposals, as can be seen in several American cities from the late 1800s to the 1970s, while 'fake beggars' who trick others into giving are recurrent figures in Hollywood silent films (Schweik 2009, pp. 108-137). In the 2010s in Sweden, it is clear that fraud continues to remain a powerful trope in the language of begging also in a project meant to confront Swedes with their intolerance towards begging migrants. Although Institutet paid Lăcătuş and Chereși to pose as beggars, Carlsson still felt 'fooled' in the end, although he did not put any moral blame on the two migrants. This suggests that Lăcătuș and Chereși were not mere passive objects displayed in a 'freak show', but 'crafty takers' 6 who took advantage of the situation as best as they could. In the second Swedish project I now wish to discuss, being exposed and agentic at the same time is also at play, although the nature of the collaboration between the artist and the begging migrant is quite different from what we see in Toleranshuvan Reloaded.

\section{Sharing Performance in It Could Have Been Me}

During the period 2012-2015, the Swedish cartoonist Sara Olausson developed a multiplatform project in close collaboration with Felicia Iosif, a woman from Romania begging in the suburbs of Stockholm where Olausson lived. The catalyst of the project was the friendship between 
Olausson and Iosif, and which Olausson decided to share publicly in an attempt to help her Romanian friend and fight prejudices against begging migrants. The project involved multiple platforms and formats that cut across aesthetic and extra-aesthetic spaces: graphic short stories; photographs; interviews with the press; a radio documentary; a Facebook page to raise funds to help Iosif and her husband build a house in Romania; street protests in support of begging migrants; a political debate on radio between Olausson and the party secretary of the Sweden Democrats, Björn Söder; and even a TEDx talk Olausson gave in Gothenburg in December 2015.

In 2015, the book Det kunde varit jag (It Could Have Been Me) came out, crediting both Olausson and Iosif as co-authors. In addition to Olausson's cartoons and own reflections, the book contains screen shots from Google Translate and Facebook, excerpts from Facebook posts, photographs, a drawing made by Iosif's daughter, several conversations between Olausson and Iosif interpreted by Arina Stoenescu, two short interviews with other Swedes that have been involved in helping begging migrants from Romania (Anna Silver and Aaron Israelson), the text of Emil Jensen's song 'Tror du det?' ('Do You Think?'), and a brief factsheet about the Romanian Roma written by Arina Stoenescu. The book not only documents Olausson's project but, at the same time, affords her the opportunity for critical reflection on it, which is why I will use it as an interface to the forms of vulnerability at play in this project. This means that the focus of my analysis is not on the transmedial character of Olausson's project, a topic that certainly deserves critical attention, but one that lies outside the scope of this particular chapter. Instead, I use the book as a starting point from which to access vulnerability in three different respects: (i) a friendship between two women, (ii) that developed under the supervision of the media, (iii) in a Scandinavian political climate that became increasingly hostile to begging migrants from Eastern Europe.

In two separate graphic short stories, we learn the story of Sara (Olausson, born 1972) and Felicia (Iosif, born 1984), whose destinies met when Sara's five-year-old son grabbed Felicia's begging cup from where she sat on the pavement. Both stories are drawn by Olausson, first published by Pioneer Press and later reprinted in the book It Could Have Been Me. Olausson's drawing style is naïve, simple and subjective, with Olausson using a variety of lines and patterns to underline the emotional content of the situations depicted in the panels. In the reprinted edition of Felicia, black is offset with white, two shades of grey and two shades of purple 
(a darker and a lighter variant). In the reprinted edition of Sara in the same book, the colour pallet consists of two shades of red (a bright and a pale version), white, black and the same shades of grey from Felicia. The choice of colours, purple and red, respectively, underlines the feminine dimension of both graphic short stories. They are portraits of two women who step up in the public eye to tell the story of their friendship and how they were brought together.

Felicia introduces Iosif and how she ended up begging on the streets of Stockholm. It is co-authored by Olausson and Iosif, and is told in first person. Olausson lends her pen to tell Felicia's story, but it is Iosif who functions as the narrator. It is her voice that we hear. In the book It Could Have Been Me, Olausson explains how she and Iosif communicated through a 'language soup' mixing Romanian, Swedish, English and other invented words and sounds (Olausson and Iosif 2015, p. 41). This communication process was initially facilitated by Google translate, a rudimentary translation service that helped the women connect, yet it also led to misunderstandings. Eventually, Romanian-Swedish graphic designer Arina Stoenescu, whom Olausson already knew, became involved as an interpreter (Olausson and Iosif 2015, p. 43).

A pivotal moment in Felicia's graphic short story is her father's deadly chainsaw injury. This tragic event is presented as the beginning of the demise of Felicia's family. 'Mother was 33 years old, with six children and a million tears, poverty's jaws closed around us', explains the narrator in voice-over against many streams of purple teardrops shedding from two stylized eyes sketched as a bundle of lines (Olausson and Iosif 2014, p. 14). The visual motif of the drop ties Felicia's difficult situation in Sweden as a homeless migrant to the sorrow and pain left after her father's death: cold raindrops in Sweden that prevent her laundry from ever drying, raindrops and 'a million' teardrops on the day Felicia's father died, teardrops falling from Felicia's eyes when she shamefully confesses that her family in Romania thinks she has a job in Sweden: 'Mother does not know I am sitting here. Nor do my siblings' (Olausson and Iosif 2014, p. 14) (see Fig. 11.2).

Felicia's friendship with Sara is presented as the result of divine intervention: 'I prayed to God for a friend. Maybe he heard me' (Olausson and Iosif 2014, p. 15). Sara's friendly gesture to sit down beside Felicia provides a much needed emotional buffer in a cold and wet country indifferent — and, at times, directly hostile — to begging migrants. 'Today, she sat down beside me. Her name is Sora. In my language, Sora means 


\section{MOTHER DOES NOT KNOW I AM SIIIING HERE. NOR DO MY SIBLINGS.}

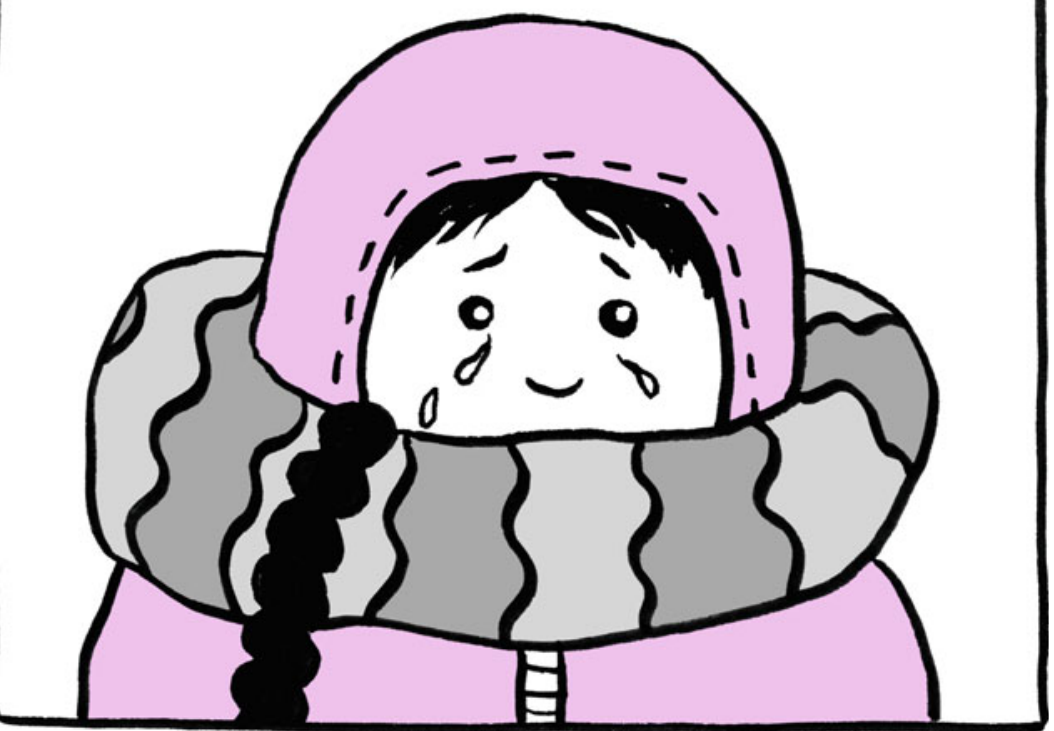

Fig. 11.2 Tears falling down Felicia's face. Panel from the graphic short story Felicia (2015) (@ Sara Olausson)

sister!', says Felicia in voice-over in the last panel showing a long shot of the two women sitting next to each other covered in a black-and-white striped blanket (ibid.).

In the graphic short story Sara, the reader gets to hear Olausson's version of how she met and befriended Felicia. Like Felicia, Sara is also told in first person narrative, this time from Sara's perspective. Sara introduces herself as a mother of three who struggles: 'But life is not easy. There is something in me that is broken' (Olausson and Iosif 2015, p. 23). ${ }^{7}$ She confesses having suffered from postpartum depression and continues to draw her professional anxieties, existential dilemmas and hectic daily routines. The first meeting with Felicia is presented as a turning point in Sara's life. In the last panel of the story, we see Sara and Felicia sitting next to one another in a frontal long shot, holding arms, both looking 
down at a little bird in the right corner of the panel. Sara confesses in voice-over: 'She (Felicia) opened my eyes and the door to something I could not imagine' (Olausson and Iosif 2015, p. 38).

Unlike Felicia, which makes extensive use of voice-over, Sara is less text based and more dialogic. Many panels have no text whatsoever and several panels use only speech bubbles to capture Sara's inner thoughts and her brief interactions with others. The visual motif of the drop encountered in Felicia is also used in Sara, both the raindrops and the teardrops. In fact, Olausson starts her story with a frontal medium closeup of herself dressed in a black coat with a black-and-white striped scarf wrapped around her neck against a grey sky covered in white raindrops: 'My name is Sara. I walk around here every day as if I were in an aquarium' (Olausson and Iosif 2015, p. 22) (see Fig. 11.3). The cold and wet

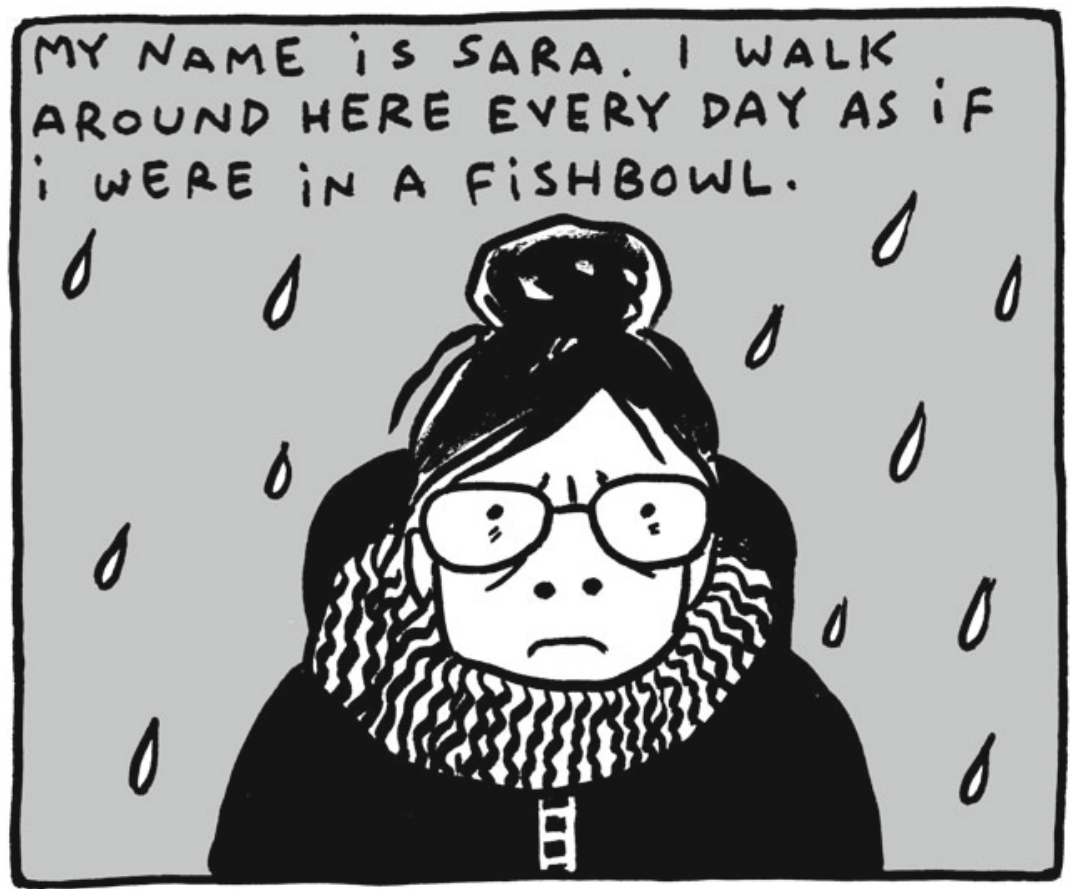

Fig. 11.3 Raindrops falling down on Sara. Panel from the graphic short story Sara (2015) (@ Sara Olausson) 
Swedish climate, in which Felicia's laundry and tears never dry, is heavy also for Sara, who feels 'angry', 'obnoxious', 'infinitely tired', and 'broken' (Olausson and Iosif 2015, pp. 22-23). The night after the interaction between Sid and Felicia, Sara is lying in bed shedding many tears (Olausson and Iosif 2015, p. 37). It is as if Felicia's unexpected gesture to give Sid a coin from her begging cup unleashes the rain Sara has accumulated inside herself. Two women, one from Romania and the other from Sweden, are about to become friends against all odds, because of all the tears.

In the book It Could Have Been Me, Olausson reflects on the challenges of developing this friendship in the spotlight of the camera. Olausson's avid engagement to help Iosif and other begging migrants from Eastern Europe attracts the attention of the media. On her first trip to Romania to visit Iosif in her home, a film team follows the two women closely. In addition, Olausson takes audio recordings of the conversations between her and Iosif. In a series of 13 panels in black and white, which are published in the book It Could Have Been $M e$, we see Olausson holding a recorder in front of Iosif. Both she and Iosif are in tears, while the back of Arina Stoenescu's head pops into the foreground of the panel: 'It is like participating in a docusoap. It is difficult, but it has to be like this now. This is important. Everyone must listen' (Olausson and Iosif 2015 , p. 62). The recordings from Romania are later to be included in a 29-minute radio documentary entitled Sara och Felicia-vem hjälper vem? [Sara and Felicia: Who Helps Who?]. Made by Maria Ridderstedt for the radio show Tendens on Sveriges Radio, the radio documentary aired on 13 October 2014. In addition to Olausson's recordings from Romania, Ridderstedt included excerpts of interviews with Olausson in which the artist talks openly about her family's frail economy.

In the book It Could Have Been Me, Olausson clarifies why she chose to talk about economic strains in a radio documentary about begging:

I choose to expose my own difficult situation so that people get it that I do not have some magical powers or economic resources. My economy is at the moment hard pressed as I live in a small three-room apartment of 57 square meters together with my husband and our three children. (Olausson and Iosif 2015, p. 105)

In the same book, Olausson also discusses how her decision to expose herself derailed the entire focus away from begging, and towards her own 
parenting and giving skills. One listener was so provoked by Olausson's confessions on the radio that she sent her a personal message on the Facebook page It Could Have Been Me in which she accused her of serious child neglect. In the book, Olausson quotes the entire Facebook message, but without revealing the name of the sender, together with her reply, in which she reassured all the 'haters in the inbox' that she was a good caretaker and warned them that she would post their 'hateful' messages publicly if they did not stop (Olausson and Iosif 2015, p. 105). And if the 'haters' demonized Olausson as an irresponsible mother, others glorified her generosity (Olausson and Iosif 2015, p. 65). In the media stir, Iosif and other begging migrants are pushed into the background, while details about Olausson's personal life and her dedication to help begging migrants are foregrounded. This comes at a price for Olausson. In a Facebook post from January 2015, Olausson writes: 'Tired. Resigned. There is not much happening on this page right now... But hang on, I will come back./Sara' (Olausson and Iosif 2015, p. 105).

The friendship between Olausson and Iosif received a great deal of public attention not only because of its unique character, but also because of the political stir created by the far-Right nationalist party Sweden Democrats in connection with their anti-begging poster campaign referred to earlier in the chapter. As already mentioned, Sveriges Radio invited Olausson to debate against Björn Söder from the Sweden Democrats in a morning news programme on their main channel Pl (Pl-morgon 2014). In the book It Could Have Been Me, Olausson includes some reflections on her encounter with Söder. She confesses the debate with the politician from the Sweden Democrats was one of the most challenging things she did in connection with the project, a political confrontation that required mental preparation. She envisioned Söder as a vulnerable infant and initiated small talk with him before the debate. During the debate, she looked him in the eye and met his arguments with mindfulness (Olausson and Iosif 2015, p. 131).

If Björn Söder represents a party with which Olausson completely disagrees, at another point in the book the artist identifies herself with a Sweden Democrat when doubt sneaks in and she starts questioning her endeavour. On her fourth visit to Romania, Olausson has to 'fight against her inner Sweden Democrat' when she realizes that the needs of the poor are too big for her to appease and she feels that she is being taken advantage of: 
Exhaustion turns into anger. I should not follow the anger. I think the same thoughts; I feel the same feelings like a Sweden Democrat. Send them home so that I can walk around and shop in peace! Leave me alone at the metro station and stop playing the accordion when I want to have it quiet and read a book! (Olausson and Iosif 2015, p. 107)

A dedicated helper, Olausson too is vulnerable to a political discourse that projects vulnerability onto the begging migrants in order to exclude them from Sweden at the same time as it deploys the language of vulnerability to protect Swedish privilege. This speaks of how the multiplatform project It Could Have Been Me exposes not only Iosif's vulnerability as a poor migrant begging on the streets of Stockholm, where she endures cold, indifference, blatant racism and eviction, to name a few. It also flags out Olausson's own vulnerability: an economically pressed mother of three children, whose husband decides to move out and ask for divorce (Olausson and Iosif 2015, p. 137); a cartoonist who earns less in comparison to other artists working in other kinds of media (Olausson and Iosif 2015, p. 137); a well-meaning Swede who, at times, feels the demands of the poor become unreasonable (Olausson and Iosif 2015, p. 107); a storyteller dependent on rudimentary communication tools such as Google translate and whose story about Felicia changes from the graphic short story Felicia to the book It Could Have Been Me once Arina Stoenescu steps in and helps to interpret, clarifying that Felicia and her family knew very well she would come to Sweden to beg (Olausson and Iosif 2015, pp. 80-83).

\section{Begging Migrants in Art AND THE TACTICS OF VULNERABILITY}

Toleranshuvan Reloaded and It Could Have Been Me are examples of how contemporary Scandinavian artists initiate collaborations with begging migrants from Romania in an effort to engage with sociopolitical challenges facing Scandinavian societies today. Theorizing how artists employ participants from outside an artistic context in their work, Claire Bishop (2006) institutes a distinction between antagonistic and convivial art, whereby the first underlines discomfort and frustration in the protected space of the museum, while the latter cultivates conviviality in the extra-aesthetic space of community action. Through a reconstruction of the various phases of the two Swedish projects, and with a focus on 
vulnerability, I have shown how neither Toleranshuvan Reloaded nor It Could Have Been Me easily fit Bishop's critical distinction. Toleranshuvan Reloaded starts off as a performance in the museum's white room and ends in aborted fundraising. It Could Have Been Me unfolds on different platforms that cut across aesthetic and extra-aesthetic spaces, including graphic short stories, political debates on radio and fundraising through social media. In both projects, the begging migrants from Romania lend their bodies and stories to Scandinavian artists in the hope of making enough money to build a house for their families in Romania. If Carlsson and his team concluded that Lăcătuș and Chereși took advantage of the collaboration with Institutet to maximize their income, Olausson presents Iosif throughout the project as a friend in need, despite misunderstandings and moments of doubt and frustration.

Vulnerability as a condition commonly projected onto the begging migrants is deployed in a tactical field, with unpredictable changes and results. In both projects, the Scandinavian artists and audiences share linguistic vulnerability with the begging migrants from Romania. Carlsson and Olausson speak of how communication was truncated by the lack of a common language, while the visitors of Toleranshuvan Reloaded reported discomfort and frustration in the absence of an interpreter in the museum's white room. Moreover, Olausson shares vulnerability with Felicia Iosif when she decides to expose herself not only by sitting on the pavement next to her friend, but also when she talks publicly about her frail economy, mental struggles and family conflicts. Olausson's engagement comes at a great price: her parenting skills are questioned; she goes through a break-up as the project comes to an end and is disarmed when faced with the increasingly hostile political climate to begging migrants in Scandinavia. Unlike her colleagues at Institutet, who only reference this political climate to create discomfort in the art room, Olausson uses her project as a platform to take an active role in the political debate, such as when she meets Björn Söder from the Sweden Democrats in a radio debate. This makes Toleranshuvan Reloaded a safer project for the artists themselves, although Lăcătus, and Chereși seem to have highjacked the artistic gesture when they allegedly lied about their background. 


\section{Notes}

1. The terms used to describe citizens of Romania who beg on the streets of Scandinavian cities vary greatly across and within the Scandinavian countries, including denominations that underline administrative categories ('EU-migrants'), ethnic categories ('Roma', 'Gypsy'), national categories ('Romanians') and socioeconomic categories ('street workers') (Djuve et al. 2015, pp. 10-11). All these denominations are politically charged, as is the term 'beggar' itself. Given the focus of the chapter on the practice and language of begging, I have chosen the phrase 'begging migrants from Romania' to refer to those Romanian nationals who end up begging abroad. I use the term 'beggar' to describe strictly the performances commissioned by Scandinavian artists such as those at Institutet and in which real people are asked to play beggars for an audience.

2. In her book The Cultural Politics of Emotions, Sara Ahmed (2004) argues that emotions work similarly to money: the more they circulate, the more effective they become. Ahmed shifts the attention away from what emotions are towards what emotions do, and to the effects emotions generate through circulation. I am influenced by Sara Ahmed in the way I understand emotions and how I track them down in the media debates and the PR material released in connection to the two artistic projects I analyse in this chapter.

3. In January 2015, the Conservative and Progress parties in Norway issued an official proposal to ban begging nationwide. In this official document, begging migrants from Eastern Europe were described as vulnerable to human trafficking, while the criminalization of begging was seen as the only effective measure by which to address the vulnerability of this group of people (The Department of Justice 2015). Similar arguments became central in the debates sparked by the TV documentary Lykkelandet ('The Happy Country', NRK 2017), which is Norway's most viewed TV documentary to date, leading to unprecedented public engagement (Fordal 2017).

4. This and all the following translations from Carlsson are mine.

5. This and all the following translations from Stenbäck are mine.

6. Discussing Norwegian missionary work in Cameroon, the Norwegian anthropologist Marianne Gullestad coins the term 'crafty takers' to capture how Cameroonians in key positions have, over the years, developed new, creative forms of dishonesty to embellish developmental aid funds (Gullestad 2007, p. 277).

7. This and the following English translations from the Swedish book It Could Have Been $\mathrm{Me}$ are mine. 


\section{REFERENCES}

Ahmed, S. (2004). The Cultural Politics of Emotion. New York: Routledge.

Ankersen, D. (2015, January 28). Här ställs tiggare ut som konst. Dagens ETC, p. 10.

Asplund, M. (2014, May 13). Folk rasande på SD-kampanj mot tiggeri. Aftonbladet. https://www.aftonbladet.se/nyheter/article18867655.ab. Accessed 10 January 2019.

Berglund, S. (2015, January 29). Soraya Post om de utställda tiggarna: 'Låter äckligt'. ETC. https://www.etc.se/inrikes/soraya-post-om-de-utstalldatiggarna-later-ackligt. Accessed 10 January 2019.

Bishop, C. (2004). Antagonism and relational aesthetics. October, 110, 51-79.

Bishop, C. (2006, February). The social turn: Collaboration and its discontents. Artforum, 44(6), 179-185.

Butler, J. (2016). Rethinking vulnerability and resistance. In J. Butler, et al. (Eds.), Vulnerability in Resistance (pp. 12-27). Durham and London: Duke University Press.

Butler, J., Gambetti, Z., \& Sabsay, L. (2016). Introduction. In J. Butler, et al. (Eds.), Vulnerability in Resistance (pp. 1-11). Durham and London: Duke University Press.

Carlsson, A. (2017a, August 15). E-mail to author.

Carlsson, A. (2017b, October 11). E-mail to author.

Djuve, A. B., Friberg, J. H., Tyldum, G., \& Zhang, H. (2015). When Poverty Meets Affluence: Migrants from Romania on the Streets of the Scandinavian Capitals. Oslo: Fafo and Rockwool Foundation. http://www.fafo.no/ images/pub/2015/954-innmat-trykk.pdf. Accessed 10 January 2019.

Ekman, K. E. (2015, January 30). Ställ ut de rika på museum-inte de fattiga. ETC. https://www.etc.se/ledare/stall-ut-de-rika-pa-museum-inte-de-fattiga. Accessed 10 January 2019.

Fordal, J. A. (2017, June 12). Bred støtte til 'Lykkelandet'-dokumentar. NRK. https://www.nrk.no/informasjon/bred-stotte-til-_lykkelandet_-dokumentar1.13542626. Accessed 10 January 2019.

Gullestad, M. (2007). Picturing Pity: Pitfalls and Pleasures in Cross-Cultural Communication-Image and Word in a North Cameroon Mission. New York: Berghahn Books.

Institutet. (2015). Toleranshuvan Reloaded. "A pair of rubber gloves called tolerance”. http://institutet.eu/2015/01/institutet-pa-konsthallen-malmo7-toleranshuvan-reloaded-a-pair-of-rubber-gloves-called-tolerance/. Accessed 10 May 2019.

Israelson, A. (2015, January 29). Utställningen handlar inte om tiggarnas utsatthet. SVT. https://www.svt.se/opinion/article2636160.svt. Accessed 10 January 2019. 
Jackson, S. (2011). Social Works: Performing Art, Supporting Publics. New York: Routledge.

Jönsson, D. (2015, February 3). Förvirrande stark 'tiggarperformance'. Dagens Nyheter. https://www.dn.se/kultur-noje/konst-form/forvirrande-starktiggarperformance/. Accessed 10 January 2019.

Kirkerud, K., \& Baraldsnes, R. (2017, April 20). Slår full alarm om romleire: Barnehagebarn tilgrises av avføring. TV 2. http://www.tv2.no/a/9073210/. Accessed 10 January 2019.

Malmö Konsthall. (2015). The Alien Within-A Living Laboratory of Western Society. Information sheet. https://www.konsthall.malmo.se/utstallning/thealien-within-a-living-laboratory-of-western-society/. Accessed 11 May 2019.

Millroth, T. (2015, January 29). En skriande kontrast. Det är din självbild, inte tiggarnas, som prövas. Sydsvenskan, p. 5.

Norsk kringskasting (NRK). (2017). Lykkelandet ('The Happy Country').

The Department of Justice, Norway. (2015, January 22). Horing-forslag til endring $i$ straffeloven 1902 og 2005 (ny $\$ 350$ a og ny $\$$ 181a om forbud mot organisert tigging). https://www.regjeringen.no/no/dokumenter/hoeringforbud-mot-organisert-tigging/id2362547/. Accessed 10 January 2019.

Olausson, S., \& Iosif, F. (2014). Felicia. Stockholm: Pionier Press.

Olausson, S., \& Iosif, F. (2015). Det kunde varit jag. Stockholm: Kartago Förlag.

Olsson, J. (2015, April 29). Dubbelt så många tiggande EU-migranter senaste året. SVT Nyheter. https://www.svt.se/nyheter/inrikes/dubbelt-sa-mangatiggande-eu-migranter-senaste-aret. Accessed 10 January 2019.

Parsberg, C. (2015). How Do You Become a Successful Beggar in Sweden? https://ceciliaparsberg.se/how-do-you-become-a-successful-beggar-insweden/. Accessed 10 May 2019.

Pl-morgon. (2014, May 16). Debatt om SD-kampanj mot tiggeri. Sveriges Radio. http://sverigesradio.se $/$ sida/artikel.aspx?programid $=1650 \&$ artikel= 5863965. Accessed 10 January 2019.

Răducanu, G. (2015, February 10). Letter sent to Diana Baldon, Director, Malmö's Fine Arts Museum. European Roma and Travellers Forum, Strasbourg.

Rooth, P. (2015, January 28). Konstprojekt kritiseras för att objektifiera migranter. Skaines Fria. http://www.skanesfria.se/artikel/116570. Accessed 10 January 2019.

Schweik, S. (2009). The Ugly Laws: Disability in Public. New York: New York University Press.

Stenbäck, C. (2015, January 25). Fattigdom väcker tankar på Konsthallen. Skainska Dagbladet. http://www.skd.se/2015/01/25/fattigdom-vackertankar-pa-konsthallen-2/. Accessed 10 January 2019.

Traavik, M. (2014). Presserom. http://traavik.info/works/ukunst-. Accessed 10 May 2019. 
Open Access This chapter is licensed under the terms of the Creative Commons Attribution 4.0 International License (http://creativecommons.org/licenses/ by/4.0/), which permits use, sharing, adaptation, distribution and reproduction in any medium or format, as long as you give appropriate credit to the original author(s) and the source, provide a link to the Creative Commons license and indicate if changes were made.

The images or other third party material in this chapter are included in the chapter's Creative Commons license, unless indicated otherwise in a credit line to the material. If material is not included in the chapter's Creative Commons license and your intended use is not permitted by statutory regulation or exceeds the permitted use, you will need to obtain permission directly from the copyright holder.

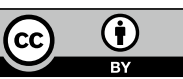

